\title{
Сохранение архитектурно-градостроительных традиций малых исторических городов Калужского края
}

\author{
В.О.Долгова, ЦНИИП Минстроя России, Москва
}

Памятники истории и культуры малых городов и окружающий их ландшафт являются национальным достоянием. Современное развитие малых городов требует бережного подхода к их историко-культурному наследию. В основу освоения уникальных исторических территорий малых городов должны быть положены исторический, экологический и ландшафтный принципы. Архитектурный облик прошлых веков сохраняется в городской застройке в сочетании с культовыми сооружениями. Уникальный колорит малым городам придаёт разнообразие окрестных природных ландшафтов. На протяжении многих веков истории Калужского края создание городов непрерывно было связано с закономерным процессом закрепления рубежей государства на новых территориях и их заселением. Большинство древних городов сохраняли свою средневековую планировку до конца XVIII века.

В эпоху правления Екатерины II политическое, промышленное и административно-территориальное преобразование государства вызвало фундаментальное переустройство русских городов-крепостей, согласно которому были разработаны и утверждены в Сенате новые регулярные планы городов. Большая заслуга в преобразовании Калуги и губернии принадлежала архитектору-градостроителю П.Р. Никитину, под руководством которого были разработаны регулярные планы городов Калужской губернии. Приобщение к европейским тенденциям в архитектуре и градостроительству с сохранением национальных традиций изучено ещё недостаточно.

Сегодня историко-культурная среда малых исторических городов в большинстве своем утрачивается в угоду коммерческой составляющей. 0пыт преобразования городов в исторические периоды в соответствии с требованиями времени уникален по многим причинам, которые необходимо ещё исследовать. В современном пространственном развитии и благоустройстве исторических малых городов следует бережно относиться к окружающей природе и сохранять национальное историко-градостроительное и архитектурное наследие, которые содержит огромный ресурс обеспечения качественной и уникальной среды обитания.

Ключевые слова: малые исторические города, генплан города, архитектурный облик, ландшафт, национальные традиции, преобразование.
Preservation of the Architectural and Urban Planning Traditions of Small Historical Towns of the Kaluga Region

V.O.Dolgova, TsNIIP Minstroy Rossii, Moscow

Historical and cultural monuments of small towns and the surroundinglandscape are a national treasure. The modern development of small towns requires a careful approach to their historical and cultural heritage. The development of unique historical territories of small towns should be based on historical, ecological, and landscape principles. The architectural appearance of the past centuries is preserved in the urban development in combination with religious buildings. The unique flavor of small towns is given by the variety of surrounding natural landscapes. Throughout many centuries of the history of the Kaluga region, the emergence of cities has been continuously associated with the natural process of securing the borders of the state in new territories and their settlement. Most of the ancient towns retained their medievallayout until the end of the 18 th century.

During the reign of Catherine II, the political, industrial, and administrative-territorial transformation of the state caused a fundamental reorganization of the Russian fortress-towns, whichled to the development and approval by the Senate of the new regular city plans. Great merit in the transformation of Kaluga and the province belonged to the urban planner P.R. Nikitin, under whoseleadership the regular plans of the towns of the Kaluga province were developed.

Today, the historical and cultural environment of small historical towns is mostly lost in favor of the commercial activity component. The experience of transforming towns in historical periods in accordance with the requirements of the time is unique for many reasons that still need to be investigated. When designing spatial development and landscaping of historical small towns, one should take care of the surrounding nature and preserve the national historical, urban planning, and architectural heritage, which contains a huge resource for providing a high-quality and uniqueliving environment.

Keywords: small historical towns, general plan of the town, architectural appearance, landscape, national traditions, transformation. 
Историко-культурный каркас Калужской области представлен историческими поселениями и другими объектами историко-культурного наследия. Размещение старинных городов Калужской земли - по берегам судоходных рек с притоками, раскрывает принцип их возникновения. Населённые пункты могли увеличиваться или исчезать на время, затем вновь воссоздаваться, смещаться, но всегда тяготели к рекам как коммуникациям. Сухопутные дороги также играли немаловажную роль в становлении, развитии или угасании населённых пунктов.

Значимый градообразующий фактор и характерная особенность Калужской земли - прохождение рубежей Великого княжества Московского и Великого княжества Литовского по главным рекам Оке и Угре. Необходимость охраны рубежей ставила перед московской великокняжеской властью задачи создания пунктов обороны, освоения и заселения этих земель. Именно на этих значимых для Московского государства рубежах возникали калужские города, служа защитой русского государства (рис. 1).

Географическая характеристика русла рек также имела значительную роль в формировании городов и сельских поселений. Так, левые - «московские» берега рек Оки и Угры - высокие и обрывистые, что способствовало более лёгкому

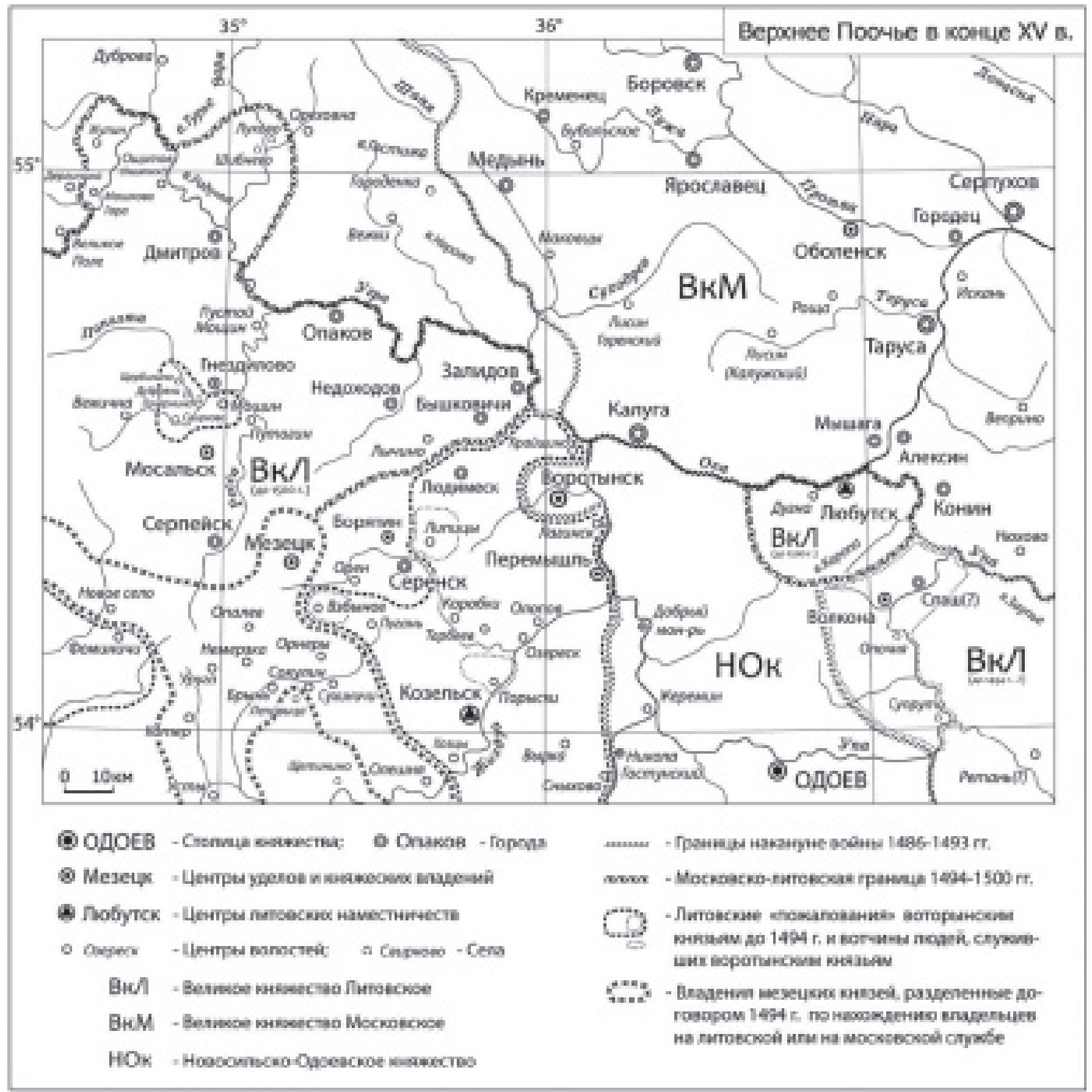

Puc. 1. Карта Верхнего Поочья в конце XV века (из открытых источников сети Интернет) 
процессу их укрепления. Закономерно, что большинство исторических калужских городов размещаются именно на левой стороне рек Оки и Угры. К юго-западу от русла этих рек города сосредоточены менее плотно, а далее и совсем редко. Можно выделить ещё одну особенность, зависящую от времени освоения края при задачах обороны государства. Характерно, что более южное расположение населённого пункта указывает на его сравнительно молодой возраст, соответственно тут меньше и плотность населения (таблица 1).

Данное обстоятельство подтверждается и системой размещения монастырей на территории современной Калужской области: к югу от города Козельска, также, как и к югу от городов Мещовска и Мосальска, не было основано монастырей ни в древности, ни в XIX столетии [1; 2]. Более поздние оси расселения возникли в XIX столетии и связаны с МосковскоВаршавским шоссе и пересекающими территорию Калужской губернии железными дорогами.

Формирование архитектурного облика исторических городов Калужского края определялось их оборонительными функциями, особенно в период XIII-XIV веков. История строительства деревянных крепостей не сохранила имён зодчих. Создание крепостей с их валами, рвами, стенами и башнями носило коллективный характер, ещё не выделились профессиональные зодчие [3, с. 21]. Со второй половины XVII столетия начинается мирное строительство калужских городов, так как государственная граница отошла от реки Оки к реке Днепр.

Императрица Екатерина II в сопровождении митрополита Московского и Коломенского Платона (Левшина) почтила своим посещением Калугу 15 декабря 1775 года. Эта дата во многом определила будущее градостроительного дела Калужского края. Уже через полгода - 24 августа 1776 года, была образована Калужская губерния с центром наместничества в городе Калуге. Калужский генерал-губернатор М.Н. Кречетников еще в 1775 году был назначен тверским губернатором, а затем в 1776 году он обустраивает Калужскую губернию, после этого, в 1777 году - Тульскую. После учреждения Рязанского наместничества в 1778 году М.Н. Кречетников стал во главе трёх губерний: Калужской, Тульской и Рязанской [4, с. 298]. Таким образом, в управлении одного человека было сосредоточено ядро территорий исконно русских земель, своеобразный щит южных и юго-западных древних окраин Московии.

Михаил Никитич Кречетников, будучи и сам амбициозным человеком, стремился к тому, чтобы главные города губернии - Калуга и центры образованных уездов, стали бы в некоторых отношениях сравнимы со столицами империи - Петербургом и Москвой. Главнейшим помощником Кречетникова М.Н. в деле переустройства уездных городов под новые административные задачи стал опытный зодчий П.Р. Никитин, пользующийся огромным уважением у нового губернатора.

Значительные усилия приложил П.Р. Никитин к архитектурно-строительным работам, производившимся в Калужской губернии. Петр Романович Никитин проработал в Калуге и губернии более шести лет (с момента образования губернии в 1776 году и практически до самой смерти, случившейся в 1784 году). Он оставил после себя неизгладимое наследие переформатировал древнерусское поселение в имперский город, увековечил себя непосредственно в архитектуре самих зданий и в созданных регулярных планах Калуги и уездных городов Калужской губернии. Основные черты этих генпланов продолжили своё развитие и в некотором роде остались в современной градостроительной планировке центров уездных, ныне районных исторических городов Калужского региона.

Генеральные планы городов Калужской губернии, разработанные под руководством П.Р. Никитина, учитывали особенности планировок старинных городов, возможность включения отдельных памятников истории и культуры в новые градостроительные структуры. Подобная работа была особо ответственной, при том, что делалась достаточно спешно в условиях острой необходимости государственного управления новообразованными административными единицами. С 1777го по начало 1778 года были утверждены генеральные планы городов Калуги, Козельска, Тарусы, Медыни, Жиздры, Мещовска, Перемышля, Мосальска, Малоярославца, Боровска, Серпейска, Лихвина. Все перечисленные города имели древнюю историю.

Таблица 1. Города и районы Калужской области

\begin{tabular}{|c|c|c|}
\hline Район & Районный центр & Дата основания \\
\hline Бабынинский & пос. Бабынино & XIX $\mathrm{B}$. \\
\hline Барятинский & с. Барятино & Конец XIX в. \\
\hline Боровский & r. Боровск & $1358 \mathrm{r}$. \\
\hline Дзержинский & г. Кондрово & $1615 r$. \\
\hline Думиничский & пгт. Думиничи & $1730 \mathrm{r}$. \\
\hline Жиздринский & г. Жиздра & 1146 r. \\
\hline Жуковский & г. Жуков & XVII в. \\
\hline Износковский & с. Износки & $1776 \mathrm{r}$. \\
\hline Кировский & г. Киров & $1744 \mathrm{r}$. \\
\hline Козельский & г. Козельск & $1146 \mathrm{r}$. \\
\hline Куйбышевский & с. Бетлица & 30-e rr. XX B. \\
\hline Людиновский & г. Людиново & $1626 \mathrm{r}$. \\
\hline Малоярославецкий & г. Малоярославец & $1389 \mathrm{r}$. \\
\hline Медынский & г. Медынь & $1386 \mathrm{r}$. \\
\hline Мещовский & r. Мещовск & $1243 \mathrm{r}$. \\
\hline Мосальский & г. Мосальск & $1231 \mathrm{r}$. \\
\hline Перемышльский & с. Перемышль & $1152 \mathrm{r}$. \\
\hline Спас-Деменский & г. Спас-Деменск & $1146 \mathrm{r}$. \\
\hline Сухиничский & г. Сухиничи & $1440 \mathrm{r}$. \\
\hline Тарусский & r. Tapyca & $1246 \mathrm{r}$. \\
\hline Ульяновский & c. Ульяново & $1610 \mathrm{r}$. \\
\hline Ферзиковский & п. Ферзиково & XVIII в. \\
\hline Хвастовичский & с. Хвастовичи & $1494 \mathrm{r}$. \\
\hline Юхновский & г. Юхнов & XV B. \\
\hline
\end{tabular}


Ключевой особенностью планировочных структур городов, созданных П.Р. Никитиным, является принцип сохранения традиционного центра города и перенесение в него функций нового административного центра. Архитектор Г.К. Смирнов констатировал любопытный факт: октогональные (восьмиугольные) площади строились во второй половине XVIII века лишь в уездных городах Калужской, Тульской и Рязанской губерний [5, с. 75]. Началом послужила Фонтанная площадь в Твери по проекту П.Р. Никитина. Например, в плане города Козельска на кремлёвском холме была предусмотрена восьмиугольная площадь, обстроенная казёнными зданиями (рис. 2). В центре её поставлен собор, замыкающий перспективу главной магистрали.

Октогональная площадь Козельска отличается от тверской расположением в живописном месте - на высоком берегу реки Жиздра. Озеленённая пойма реки, в сторону которой раскрывается центр города, создаёт контраст с регулярной застройкой и обогащает всю композицию живописными ландшафтами.

В творчестве выдающегося архитектора-градостроителя П.Р. Никитина отчётливо прослеживается стремление к лучшему использованию природных условий и местных особенностей каждого города при создании строгих регулярных композиций, смягчаемых причудливыми речными излучинами, видовыми

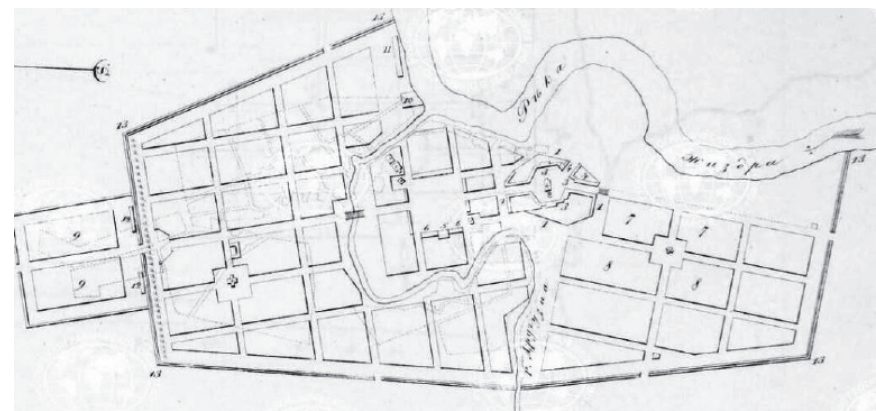

Pис. 2. «План Калужского наместничества городу Козельску» 1777 года (источник: [http://loveki.ru/museum/maps/ gub_kaluga/4.jpg)

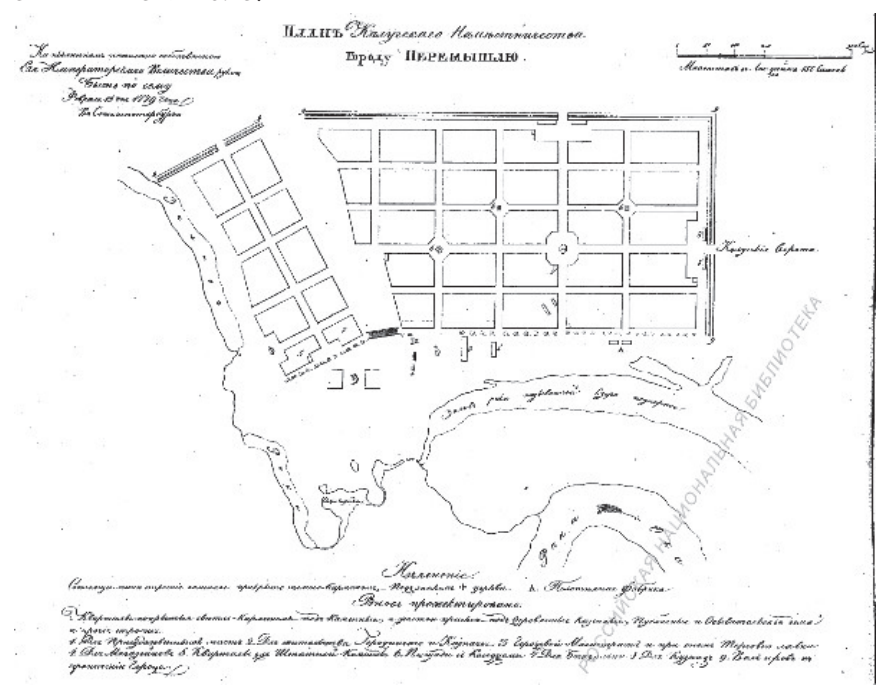

Puc. 3. План города Перемышль 1782 года (источник: https:// upload.wikimedia.org/wikipedia/commons/4/4С/Планы_городов_ из_Полного_собрания_законов_Российской_империи_133.jpg) набережными, площадями соборных и приходских церквей с учётом древних городищ [6, с. 314]. Характерным примером может служить древний город Перемышль, где сохранялись традиционные места кремля, острога, системы земляных валов. По плану планировку города преобразовали в регулярную, но оставили рельеф в естественном состоянии, не затронутым. Центр города остался на прежнем месте - над обрывом (рис. 3).

На плане города Перемышль 1782 года отмечено два древних городища: Старое и Новое, разделённых Пушкарским рвом. Древнейшая заселённая часть Перемышля - Старое городище - представляет собой холм с обрывистыми, почти отвесными склонами, спадающими к широкой пойме Оки. С холма открываются виды на озёра старицы в пойме реки: озеро Бездонное и озеро Хохловское (бывшее Резванское). При этом не исключено, что ранее река Ока несла свои воды у самой подошвы холма.

На другой стороне Пушкарского рва расположен такой же холм с отвесными крутыми склонами - Новое городище. Объяснение наименования городищ пока неизвестно, и происхождение их остаётся мало исследованным.

На Старом городище Перемышля ещё высятся руины самого древнего памятника Перемышля - Успенского собора (рис.

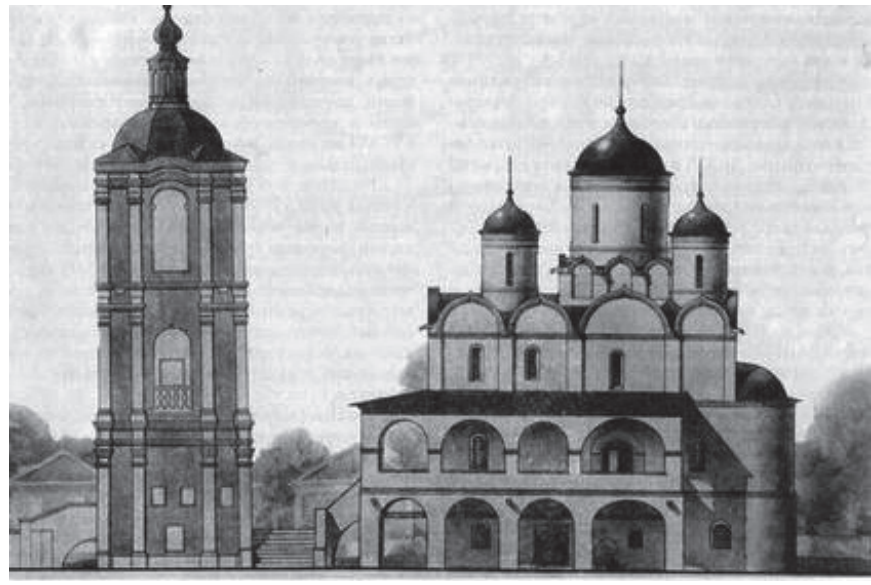

Рис. 4. Проект собора Успения Пресвятой Богородицы. Город Перемышль Калужская губерния. Учёные, исследовавшие храм, сделали реконструкцию его прежнего облика (источник: https://cdn-s-static.arzamas.academy/storage/picture/7069/ gallery_picture-08f0b17c-4e4e-4519-acf7-ad4202507b1c.jpg)

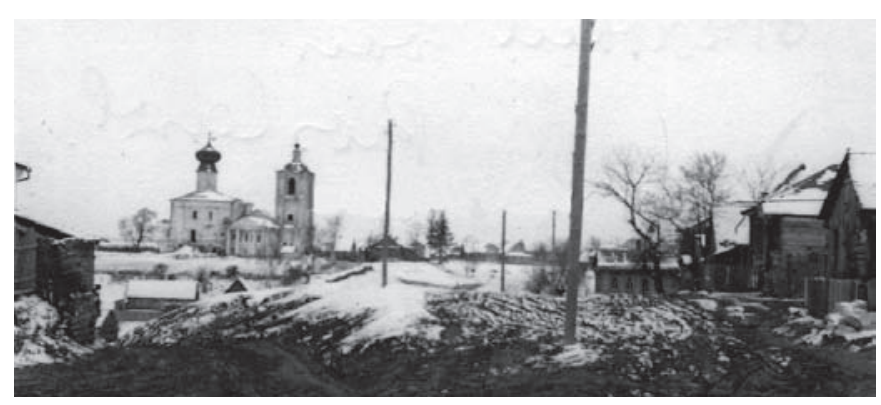

Рис. 5. Город Перемышль. Собор Успения Пресвятой Богородиц. Фото 1941 года (источник: https://pastvu.com/_p/ a/r/y/8/ry82kuu2abbmuguioh.jpg) 
4, 5). Время закладки существующего храма не установлено, но этот вопрос стал занимать исследователей уже в XIX веке. Академик архитектуры М.Т. Преображенский связывал закладку собора с включением города в состав Московского Великого Княжества в конце XV века [7]. В настоящее время исследователи в основном сходятся во мнении о принадлежности храма к эпохе Ивана Грозного.

В 1960-е годы были проведены обмеры храма, разрабатывались проекты реставрации для его восстановления в первоначальном облике, а в 1972 году произошли обрушения. В наше время судьба храма не ясна, и сегодня это одни из самых величественных руин города.

На Новом городище Перемышля, откуда проходит дорога к центру города, возвышается храм в честь сошествия Святого Духа, построенный в 1767-ом или 1781 году (рис. 6).

Несмотря на то, что храм считается действующим, восстановительные работы ещё далеки до окончательного завершения. Территория у храма традиционно у местного населения называлась «бульваром». В настоящее время от «бульвара» остались несколько деревьев. Сам бывший бульвар имеет смотровую площадку, с которой открывается широкая панорама на окрестности (рис. 7).

Бульвар был недавно реконструирован, замощён булыжной плиткой. Рядом с храмом Святого Духа на бульваре устроены детская и спортивная площадки. Благоустроенность территории очевидна, но из-за постройки ресторанного комплекса и детской и спортивной площадок на территории городища в непосредственной близости от храма нарушена гармония старинного места, потеряна связь веков - нить, соединяющая прошлое с настоящим, то есть историко-культурный ландшафт. Реконструкция храма остаётся незавершённой, и непосредственно сам храм теряется среди этого «великолепия». Даже цвет булыжной плитки по цветовой гамме более гармонирует с современной архитектурой здания ресторана и диссонирует с архитектурой храма.

Теряется ощущение древнего места, и не ясен замысел архитектора по организации современного ландшафтного обустройства территории. Не понятно, для чего оставлены спиленные остова деревьев. Всё вместе разрушает культурный ландшафт на территории исторического архитектурного объекта, а эволюция этой территории представляется наглядной иллюстрацией отсутствия бережного отношения к сохранению облика исторического города.

Уездные исторические города Калужской губернии принадлежали к числу красивейших городов России. Располагались они в живописной местности на высоких берегах рек. В процессе многовекового строительства выработались традиции сооружения древних крепостей и посадов церквей со стремительно взлетающими вверх колокольнями. Они придавали неповторимый облик всему краю, красуясь на фоне мягких линий ландшафта. Примеры индивидуализации облика города и искусного использования природных условий можно увидеть прак-

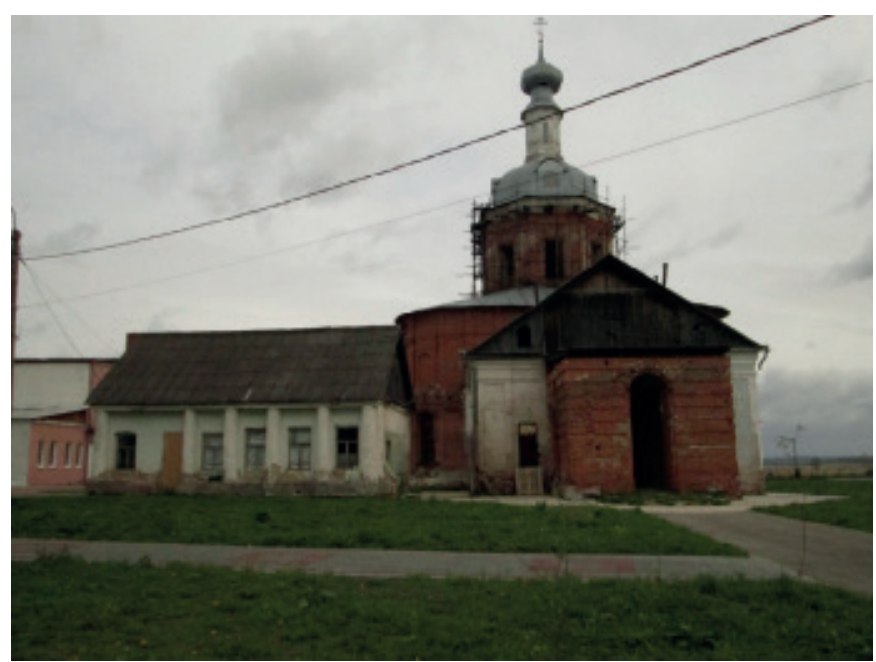

Рис. 6. Храм во имя Сошествия Святого Духа. Перемышль. Фото В.О. Долговой. 2019 год

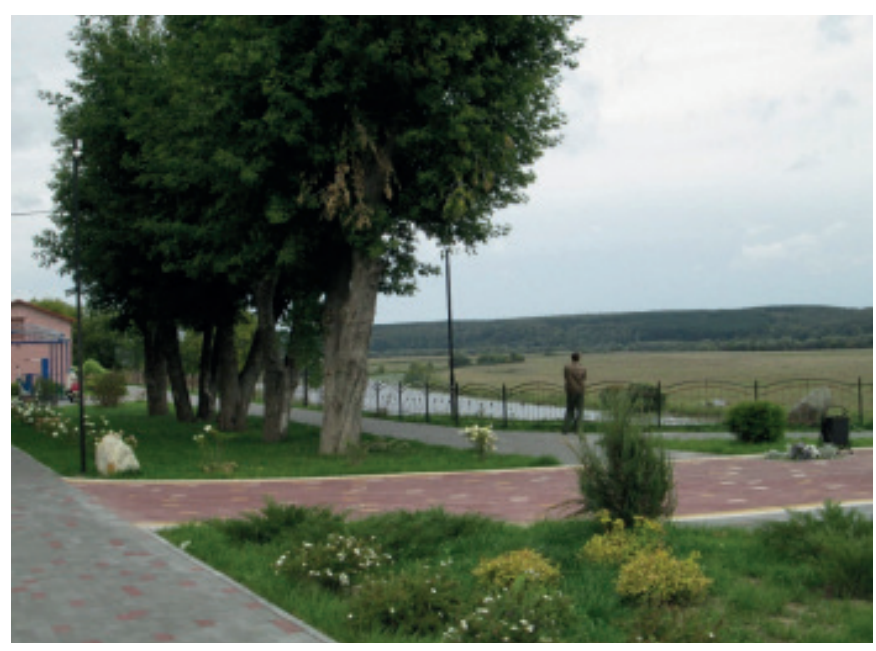

Рис. 7. Вид на окрестности Перемышля со смотровой площадки. Фото В.О. Долговой. 2019 год

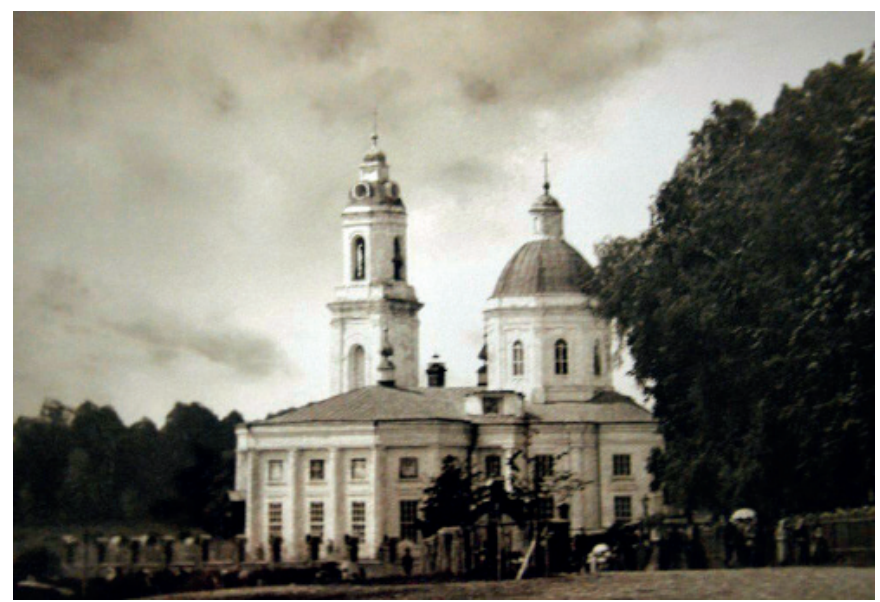

Рис. 8. Собор Константина и Елены. Город Медынь Калужской области. Фото начала XX века (источник: [https://sobory.ru/pic/02750/02754_20161002_203815.jpg] 


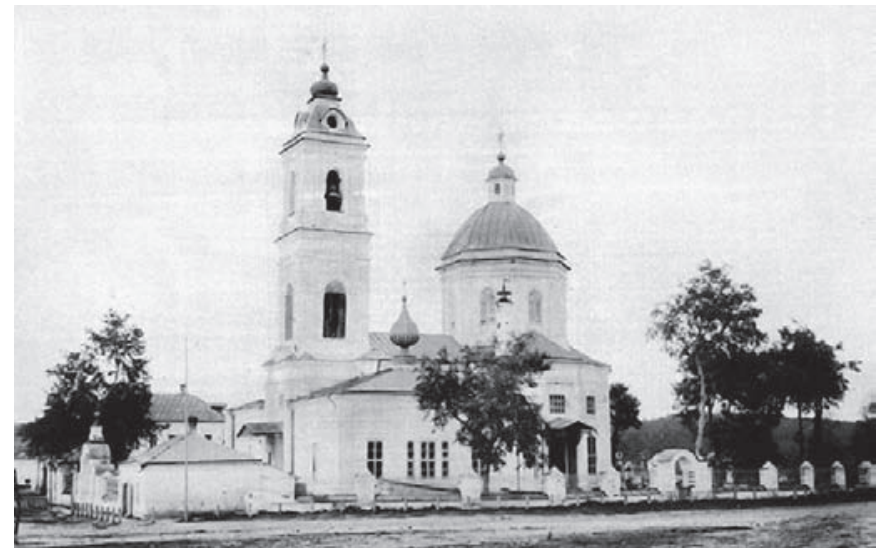

Рис. 9. Собор Петра и Павла. 1900-1912 годы. Город Таруса Калужской области (источник: https://pastvu.com/_p/a/ k/u/3/ku37rkuunkwdvvj3lh.jpg)

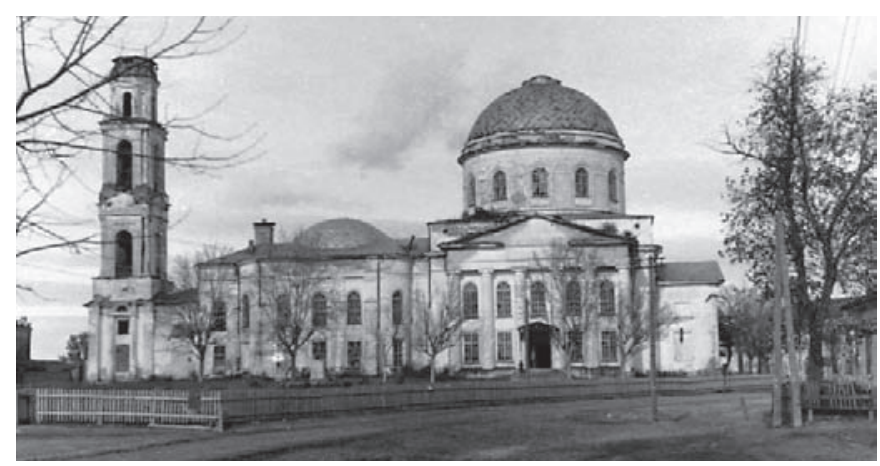

Рис. 10. Собор Александра Невского. Город Жиздра Калужской области. Фото 1941 года (источник:https://sobory.ru) pic/33400/33415_20170624_122644.jpg)

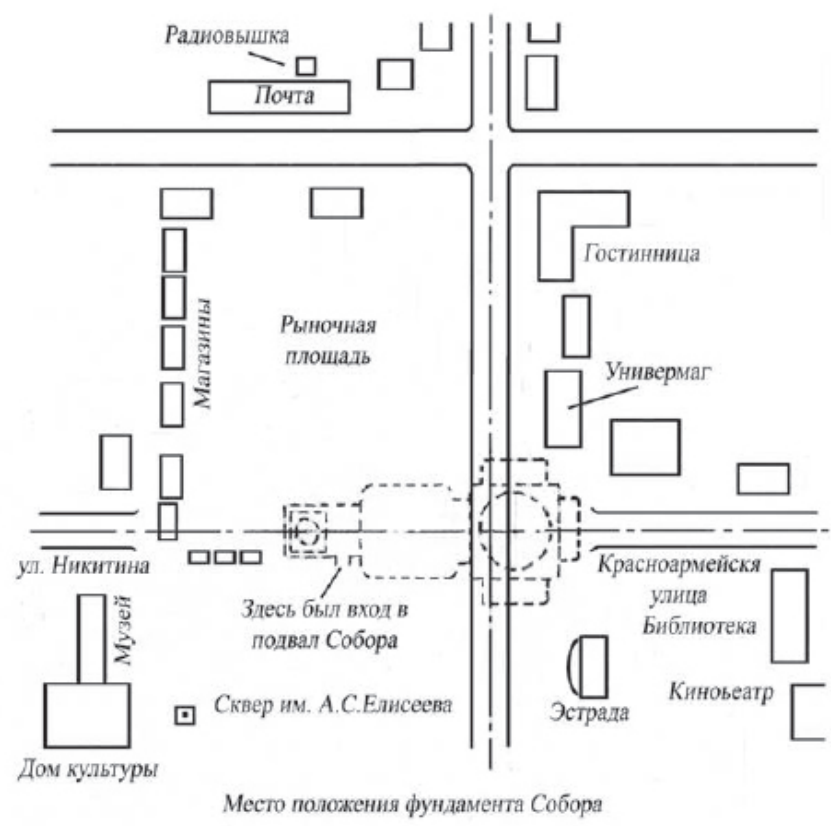

Рис. 11. Схема плана центра города Жиздры. Место фундамента собора Александра Невского обозначено пунктирной линией. Автор схемы Д. Чмыхова (источник: https:// textarchive.ru/images/1315/2629708/m66012fa4.jpg) тически в каждом уездном городе Калужской губернии конца XVIII-XIX веков. Совершенно одинаковыми были построенные в 1777-1779 годы главные соборы в городах Медынь, Жиздра и Таруса в честь присвоения им статуса центра уезда (рис. 8-10). Несмотря на однотипность проектов, постройка соборов в разных природных и местных условиях не создавала впечатления однообразия.

Наиболее печальна судьба собора Александра Невского и самого города Жиздры. После объявления Жиздры уездным городом, здесь оживилось строительство. Старый город, расположенный на правом берегу реки Жиздры, являлся первоначальным местом поселения. Но большей частью расстроился он на левом берегу. На самом высоком месте возвышался собор Александра Невского. Во время Великой Отечественной войны по заранее подготовленному плану гитлеровского командования город Жиздра был полностью разрушен фашистскими захватчиками.

Прежде чем восстанавливать город Жиздру, необходимо было разобрать руины. Проще было строить город на новом месте или даже не восстанавливать его вовсе. Существовали планы переноса районного центра на железнодорожную станцию Зикеево или в одну из близлежащих деревень. Но одна из городских легенд рассказывает, будто Сталин на таком плане синим карандашом написал: «Война не должна стирать с лица земли наши города!» [8]. Вряд ли, конечно, Верховный Главнокомандующий лично озаботился о судьбе города Жиздры, однако тем не менее было принято решение восстанавливать город на прежнем месте и в соответствии с прежней планировкой (рис. 11). Сегодня на месте собора проходит автомагистраль.

Новые постройки и планировка центральной части города далеко не всегда соответствуют довоенной. Это очень способствует тому, что место нахождение фундамента собора

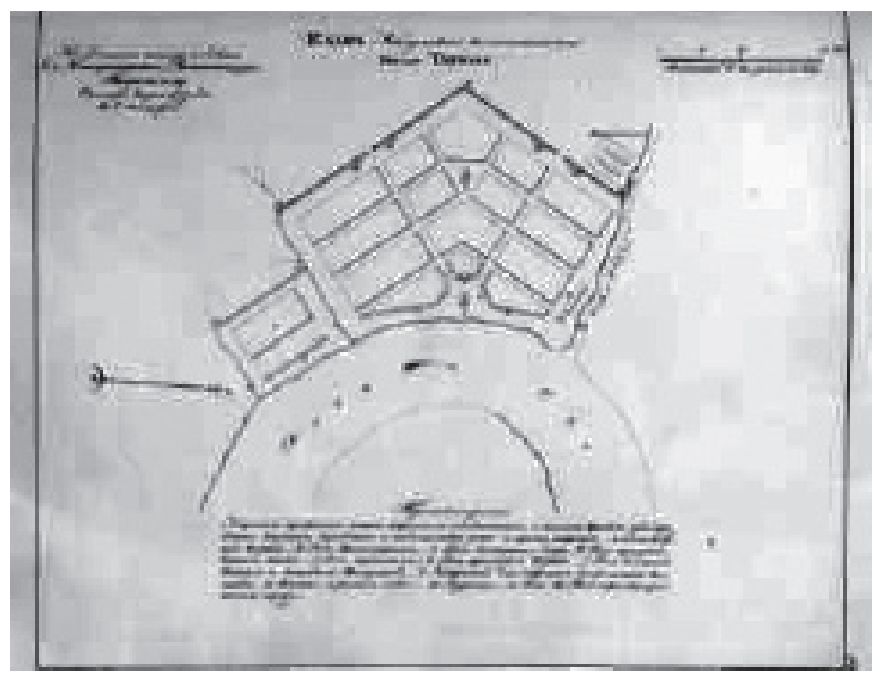

Puс. 12. План города Тарусы. 1777 год (источник: http:// loveki.ru/museum/maps/gub_kaluga/12.jpg) 
забывается, а молодые жиздринцы вообще не знают точно, где он залегает [9].

Весьма оригинальна схема плана города Тарусы, разработанная зодчим П.Р. Никитиным с учётом своеобразия тарусского рельефа и ландшафта (рис. 12). Энергичная кривая окской излучины и стремление разместить город вдоль реки на ограниченном оврагами пространстве позволили зодчему использовать приём двух пересекающихся лучей, исходящих от главной площади, имеющей трапециевидную форму и расположенной на берегу Оки на месте старого торга. С неё открываются замечательные виды на природу и заокские дали.

Городская планировка прошлого сохранилась до нашего времени. На площади находится собор святых апостолов Петра и Павла (1785-1790), построенный на месте сгоревшей Никольской церкви, известной с XVI века. Он является архитектурной доминантой города. В начале тридцатых годов XX века храм закрыли. А в 1936 году здание перестроили под Дом пионеров. Новый приход был открыт в 1998 году.

Нынешний архитектурный облик Тарусы определяет в основном его историческая структура. Город с малоэтажной застройкой, уютными улочками, многочисленными зелёными пространствами и природными окрестностями всегда привлекал к себе писателей, музыкантов, артистов, художников, при участии которых создаётся особая творческая атмосфера.

Немногие города Калужского края смогли сохранить и исторический облик, и планировку, и панорамные виды на окрестные ландшафты. Так, генеральный план застройки уездного города Медыни был составлен также П.Р. Никитиным, он же занимался наблюдением за организацией и ходом строительных работ.

Новый план города предусматривал выделение главного центра - городской площади, на которой размещались большая торговая площадь (старинный торг) и административные здания. Большая торговая площадь размещена по проекту Никитина П.Р. на месте существования древнего торга, но она была значительно расширена и приобрела квадратное в плане очертание. Всю её северо-восточную границу, в соответствии с планом, должны были занимать здания общественного назначения - «Присутственные места», «дом городничего и казначея».

В 1927 году обширную территорию главной площади «прорезала» аллея, или официально - сквер, с памятником вождю пролетариата В.И. Ленину. Прогуливаться по данному скверу невозможно, вследствие малой площади и кругового автомобильного движения, затрудняющего доступ к нему. Данное мемориально-ландшафтное произведение советской эпохи сохранилось хорошо и членит бывшую некогда обширной площадь на сектора.
В первоочередную программу общественной застройки центра города входило строительство главного собора города в честь равноапостольных царя Константина и царицы Елены (см. рис. 8). Историками творчества П.Р. Никитина выявлены документы, подтверждающие создание архитектором иконостаса в главном соборе равноапостольных Константина и Елены в городе Медыни ${ }^{1}$. Судя по официальным датам постройки типовых соборов в Медыне, Жиздре и Тарусе, собор в Медыне, вероятно, был первым и построенным по проекту П.Р. Никтина. Далее он послужил прообразом для постройки остальных аналогичных соборов, принимая во внимание, что собор в Тарусе был построен в 1785-1789 годы, то есть после смерти П.Р. Никитина (1784), и приписывается его преемнику - следующему главному архитектору Калуги и городов Калужского края - Ивану Денисовичу Ясныгину.

Размещение главного храма в Медыни на возвышенности, на месте древнего городища, выделяло его из всей рядовой застройки, делало более величественным. Сейчас храм находится почти в руинированном состоянии.

Непонятно, по чьему распоряжению на месте древнего городища Медыни, входящего, кстати, в реестры объектов археологического культурного наследия, совсем недавно был построен торговый комплекс. Своей монументальностью он превосходит остов бывшего собора и перекрывает все ландшафтные виды на окрестности [10-12].

Пренебрежение архитектурными традициями: без возрождения храма и культурного ландшафта, без внимания к существованию древнего городища, - приводит к замещению историко-культурных объектов модернистскими европеизированными архитектурными образцами. В итоге малые русские города теряют свой самобытный градостроительный облик.

$* * *$

1. Исторический облик каждого малого исторического города Калужского края своеобразен, каждый уникален посвоему, но слишком многое сегодня утрачивается. Архитекторы, планирующие развитие малых исторических городов, иногда плохо знают историю планируемого ими города, не имеют представления о том, что в этих городах ценного в историко-градостроительном отношении.

2. Объёмно-пространственные решения современных общественных зданий нарушают историческую градостроительную целостность в угоду современной функциональной организации городской среды. Например, отсутствует согласованность архитектуры современных зданий торговых центров по отношению к исторической застройке.

3. В малых городах фасады исторических зданий часто модернизируются, а не реставрируются с сохранением их

\footnotetext{
${ }^{1}$ Журналы и протоколы Калужской Казённой палаты. Рекомендация наместника Кречетникова приступить к построению почтового дома в Калуге, о построении в Перемышле корпусов присутственных мест, дома для городничего и казначея, о изготовлении иконостаса в соборной церкви Медыни // ГАК0. Ф. 86. 0п.1. Ед. хр. 72. 1782.
} 
первоначального облика. При этом применение современных материалов иногда искажает облик зданий, не позволяет в полной мере воссоздать их исторической облик.

4. Изучение и сохранение образа исторического города, преемственности культур должны играть первостепенную роль в современном пространственном развитии и благоустройстве малых городов. Неоценимы в этом деле труды и опыт зодчих прошлого по преобразованию городов под определённые социальные функции без потери самобытности. В этих работах отражается бережное отношение к окружающей природе и уважение к национальной культуре. Анализ связи проектирования архитектурных объектов с существующими охранными регламентами не рассмотрены в данной статье, так как требуют отдельного исследования.

\section{Лuтература}

1. Долгова, В.О. Историко-культурное наследие: монастыри в градостроительстве Калужских земель XIII-XVII веков. Этапы и рубежи распространения монастырей. Часть 1 / В.0. Долгова // Градостроительство. - 2019. - № 5. - С. 14-20.

2. Долгова, В.О. Историко-культурное наследие: монастыри Калужских земель XVII-XXI веков, их роль и значение в градостроительстве. Часть 2 / В.0. Долгова // Градостроительство. - 2019. - № 6. - С. 16-24.

3. Днепровский-Орбелиани, А.С. Зодчество Калужского края с древности до наших дней / А.С. Днепровский-Орбелиани. 2-е изд., испр. и доп. - Калуга : Издательство научной литературы Н.Ф. Бочкарёвой, 2005.

4. Калужская энциклопедия. 2-е изд. перераб. и доп. - Калуга: Издательство научной литературы Н.Ф. Бочкарёвой, 2005.

5. Смирнов, Г.К. Архитектурный ансамбль Фонтанной площади в Твери (вторая половина XVIII в.) / Г.К. Смирнов // Памятники русской архитектуры и монументального искусства: XVI-XX вв. Вып. 7. - М. : Наука, 2005. - С. 63-113.

6. Обухов, В.М. Русский зодчий Петр Романович Никитин / В.М. Обухов. - Калуга : Фридгельм, 2008.

7. Преображенский, М.Т. Памятники древнерусского искусства / М.Т. Преображенский. Вып. 1-4. - СПб, 1908-1912.

8. Лесютина, В.В. Город, восставший из пепла [Электронный ресурс] / В.В. Лесютина // Жиздринский районный историко-краеведческий музей. Официальный сайт. - Режим доступа: http://www.zhizdra.ru/story/s1944.html (дата обращения 20.12.2020 г.).

9. Чмыхова, Д. «Поруганная святыня». История собора в честь святого благоверного князя Александра Невского [Электронный ресурс] / Д. Чмыхова // Материалы XVI 0бластная научно-практическая конференция памяти А.Д. Юдина. - Режим доступа: https://pandia.ru/966386/ (дата обращения 20.12.2020).

10. Долгова, В.0. Сохранение историко-культурных ландшафтов как «достопримечательные места» / В.0. Долгова, 3.К. Петрова / В.0. Долгова, 3.К. Петрова // Градостроительство. - 2020. - № 1. - С. 14-22.
11. Долгова, В.О. Рекомендации по восстановлению, сохранению и развитию исторических культурных ландшафтов сельских поселений и малых городов (на примере Калужской области) / В.О. Долгова, Д.В. Долгов // Наука, образование и экспериментальное проектирование. Труды МАРХИ : Сборник статей - М. : МАРХИ, 2020. - С. 318-322.

12. Петрова, 3.К. Планировочная организации малоэтажной экологически безопасной жилой застройки / 3.К. Петрова, В.0. Долгова - М. : Новая реальность, 2019. - 250 c. - C. 52-54.

\section{References}

1. Dolgova V.0. Istoriko-kul'turnoe nasledie: monastyri v gradostroitel'stve Kaluzhskikh zemel' XIII-XVII vekov. Etapy i rubezhi rasprostraneniya monastyrei. Chast' 1 [Historical and cultural heritage: monasteries in the town planning of the Kalugalands of the XIII-XVII centuries. Stages and boundaries of the spread of monasteries. Part 1]. In: Gradostroitel'stvo [City and Town Planning], 2019, no. № 5, pp. 14-20. (In Rus., abstr.in Engl.)

2. Dolgova V.0. Istoriko-kul'turnoe nasledie: monastyri Kaluzhskikh zemel' XVII-XXI vekov, ikh rol' i znachenie $v$ gradostroitel'stve. Chast' 2 [Historical and cultural heritage: monasteries of the Kalugalands of the 17th - 21st centuries, their role and significance in urban planning. Part 2]. In: Gradostroitel'stvo [City and Town Planning], 2019, no. 6, pp. 16-24. (In Rus., abstr.in Engl.)

3. Dneprovskii-Orbeliani A.S. Zodchestvo Kaluzhskogo kraya s drevnosti do nashikh dnei [The architecture of the Kaluga region from antiquity to the present day]. Kaluga, Publishing house of scientificliterature of N.F. Bochkareva, 2005. (In Russ.)

4. Kaluzhskaya entsiklopediya. 2-e izd. pererab. i dop. [Kaluga encyclopedia. 2nd ed. revised and add]. Kaluga, Publishing house of scientific literature of N.F. Bochkareva, 2005. (In Russ.)

5. Smirnov. G.K. Arkhitekturnyi ansambl' Fontannoi ploshchadi $v$ Tveri (vtoraya polovina XVIII v.) [Architectural ensemble of Fountain Square in Tver (second half of the 18th century)]. In: Pamyatniki russkoi arkhitektury i monumental'nogo iskusstva: XVI-XX vv. [Monuments of Russian architecture and monumental art: XVI - XX centuries], Iss. 7. Moscow, 2005, Nauka Publ., pp. 63-113. (In Russ.)

6. Obukhov V.M. Russkii zodchii Petr Romanovich Nikitin [Russian architect Peter Romanovich Nikitin]. Kaluga, Fridgel'm Publ., 2008. (In Russ.)

7. Preobrazhenskii M.T. Pamyatniki drevnerusskogo iskusstva [Monuments of Old Russian Art / M.T. Preobrazhensky], Iss. 1-4. St. Petersburg, 1908-1912. (In Russ.)

8. Lesyutina V.V. Gorod, vosstavshii iz pepla [The city that rose from the ashes]. Zhizdrinskii raionnyi istorikokraevedcheskii muzei. Ofitsial'nyi sait [Zhizdrinsky regional museum oflocal history. Official site]. Access mode: http:// 
www.zhizdra.ru/story/s1944.htmlhttp://www.zhizdra.ru/ story/s1944.html (Accessed 12/20/2020). (In Russ.)

9. Chmykhova D. «Porugannaya svyatynya». Istoriya sobora $\checkmark$ chest' svyatogo blagovernogo knyazya Aleksandra Nevskogo ["Abused shrine". The history of the cathedral in honor of the holy blessed prince Alexander Nevsky]. In: Materialy XVI Oblastnaya nauchno-prakticheskaya konferentsiya pamyati A.D. Yudina [Proceedings of the XVI Regional Scientific and Practical Conference in memory of A.D. Yudin]. Access mode: https:// pandia.ru/966386/ (Accessed 12/20/2020). (In Russ.)

10. Dolgova V.0., Petrova Z.K. Sokhranenie istorikokul'turnykh landshaftov kak «dostoprimechatel'nye mesta» [Preservation of historical and culturallandscapes as "places of interest"]. In: Gradostroitel'stvo [City and Town Planning], 2020, no. 1, pp. 14-22. (In Rus., abstr.in Engl.)
11. Dolgova V.O., Dolgov D.V. Rekomendatsii po vosstanovleniyu, sokhraneniyu i razvitiyu istoricheskikh kul'turnykhlandshaftov sel'skikh poselenii i malykh gorodov (na primere Kaluzhskoi oblasti) [Recommendations for the restoration, preservation and development of historical culturallandscapes of rural settlements and small towns (on the example of the Kaluga region)]. In: Nauka, obrazovanie i eksperimental'noe proektirovanie. Trudy MARKhI. Sbornik statei [Science, Education and Experimental Design. Proceedings of MARCHI. Collection of articles]. Moscow, MARKhI Publ., 2020, pp. 318-322.

12. Petrova Z.K., Dolgova V.0. Planirovochnaya organizatsii maloetazhnoi ekologicheski bezopasnoi zhiloi zastroiki [Planning organization oflow-rise ecologically safe residential development]. Moscow, Novaya real'nost' Publ., 2019, 250 p., pp. 52-54.

Долгова Виктория Олеговна (Москва). Научный сотрудник отдела «Территориальные основы градостроительства» ФГБУ «ЦНИИП Минстроя России» (119331, Москва, просп. Вернадского, 29. ЦНИИП Минстроя России). E-mail: Dingo93@mail.ru.

Dolgova Victoria 0. (Moscow). Researcher at the Department "Territorial Foundations of Urban Development" of the Institute for Research and Design of the Ministry of Construction and Housing and Communal Services of Russia (29 Vernadskogo avenue, Moscow, 119331. TsNIIP). E-mail: Dingo93@mail.ru. 